\title{
PRACTICE OF ISLAMIC MICROFINANCE BY DIFFERENT NON-GOVERNMENT ORGANIZATION'S IN BANGLADESH: AN EMPIRICAL EVIDENCE
}

EFAT JANNAT SHAMMI

Lecturer in Finance, Department of Business Administration, Pundra University of Science and Technology, Bangladesh

*(shammi.financeru@gmail.com)

This journal is licensed under a Creative Commons Attribution-NonCommercial 4.0 International License (CC-BY-NC). Articles can be read and shared for noncommercial purposes under the following conditions:

- BY: Attribution must be given to the original source (Attribution)

- NC: Works may not be used for commercial purposes (Noncommercial)

This license lets others remix, tweak, and build upon your work non-commercially, and although their new works must also acknowledge you and be non-commercial, they don't have to license their derivative works on the same terms. License Deed Link: http://creativecommons.org/licenses/by-nc/4.0/ Legal Code Link: http://creativecommons.org/licenses/by-nc/4.0/legalcode

$A B C$ Research Alert uses the CC BY-NC to protect the author's work from misuse.

\begin{abstract}
Bangladesh is a populated country where most of the people are Muslims. Bangladesh is the birthplace and hub of microfinance. She is considered as a star performer in interest based conventional microfinance programs. Although most of the people are Muslims, she is lagging behind exploring full potentials of Islamic microfinance. Most of the Ngo's do not practice Islamic microfinance here. The present paper shows how many NGO's practice Islamic microfinance in Bangladesh. This paper suggests the NGO's about the potentials of Islamic microfinance in Bangladesh. Looking at the role of Islamic NGOs in Bangladesh, the book investigates new forms of neoliberal govern mentality supported by international donors. It discusses how this form of social regulation produces and reproduces subjectivities, particularly Muslim women subjectivity, and has combined religious and economic rationality, further complicating the boundaries and the relationship between Islam, modernity, and development. The book argues that both secular and Islamic NGOs target women in the name of empowerment but more importantly as the most reliable partners to meet their debt obligations of micro-financing schemes, including shari'a-based financing. The targeted women, in turn, experience Islamic NGOs as less coercive and more sensitive to their religious environment in the rural village community than are secular NGOs.
\end{abstract}

Keywords

Islamic Microfinance, NGO, Bangladesh.

\section{INTRODUCTION}

Microfinance was first introduced in Bangladesh with the introduction of Grameen model by Noble Laureate Prof. Dr. Md. Yunus in 1983. A large number of Microfinance Institutions (MFIs) have emerged in Bangladesh to provide collateral free loan to the poor inspired by the success of Grameen Bank. Currently, Bangladesh microfinance industry is serving about 37 million poor people: more than $90 \%$ of them are women. The experience of the last few decades suggests that the microcredit programs of NGOs have been successful in reaching the moderate poor, but the poorest of the poor are more often inadequately served or completely bypassed (Emran, \& Smith, 2014). The failures of the conventional microcredit programs may be 
attributed to higher rate of interest rate and operational cost and unwillingness of religious people to participate in interest based programs. Islamic microfinance is mainly based on Zakat and other unique funding models. Inspire of being a Muslim majority country and immense growth in Islamic banking, Bangladesh is lagging behind in promoting Islamic microfinance. The interest based conventional microfinance industry belongs to 95 percent market share of the microfinance industry while Islamic microfinance industry accounts for only 5 percent share of the market in Bangladesh. Bangladesh appeared as an independent and sovereign country in 1971 following a 9-month War of Independence. The country owns the largest deltas of the world with a total area of 147,570 sq. $\mathrm{km}$ and a high population of 150 million people. More than $85 \%$ people live in rural areas and more than $50 \%$ of population is women. Bangladesh has an agrarian economy that accommodates the major rural labor force. $85 \%$ of the population live on agriculture and contribute $40 \%$ of the total GDP. Annually GDP growth rate is $5.8 \%$ and per capita GNP is $\$ 375$. Over $45 \%$ of the population live below the poverty line, about $20 \%$ of rural households live in extreme poverty (BBS, 2009). The biggest cause of rural poverty in Bangladesh is the erratic and extreme climate. Many rural people live in areas that are vulnerable to annual flooding. Extreme climate destroys crops, homes and livelihoods. The money to rebuild people's homes and rebuy livelihoods often pushes them into deeper poverty (Rural poverty in Bangladesh, 2007). These steps are flexible. Their flexibility makes mobility from one step to another possible. In the first stage, a very poor who may lacks skills and capital participates. The waqf fund could be used to provide skills to the poor. The contract is called Waqf -Ijara contract. The second stage is the Mudaraba contract upon graduations from the first stage and the third stage is Musharakah contract. Each of these contracts has been treated separately as individual entities and later integrated into a single entity. The bonding of participants together in a cooperative manner may induce mutual benefits of parties involved and that will help to realize the optimum benefits of the model. The platform for implementing the proposed model could be formal, semi-formal or NGOs MFIs that operate on the Islamic principles.

\section{LITERATURE REVIEW OF THE STUDY}

\subsection{The needs and Prospects of Islamic Micro-finance Model}

Differing approach is required in any push to fight poverty. A solitary arrangement fits all probably won't be feasible. This reality requires diverse choices for destitution mitigation programed crosswise over countries and times. The three many years of microfinance advancement of different kinds yield little achievement so far as far as effect and taking care of neediness issues (Shetty, 2008). Different effect contemplates have demonstrated that microfinance influence examines are inclined to guileless evaluations (Kono and Takahashi, 2010) or there exist mission floats in the destinations of microfinance by charging unnecessary loan fee (Karnani, 2007, Karim et al, 2008, Adewale, 2006, Gow, 2010). Still others see that the microfinance isn't in accordance with the way of life and conviction of Muslims in numerous nations including Bangladesh where the advanced microfinance starts (Demirtuc-Kunt, 2008, money related elatedness of poor people, social and religious sensitivities of Muslim social orders must be given due consideration. That will consolidate substantial help of poor population in the formal budgetary frameworks in Muslim nations and networks. 
This improvement prompts rise of couple of Islamic microfinance establishments in some Muslim nations and networks (Karnani, 2007, Karim et al, 2008,). In any case, the elective microfinance experiences the current structure of surprising expense of organization, costly items (El-Karanshawy, 2007) which may not empower it to accomplish formative goal or maslaha in the general public (El-Minsawi, 2006).

Ahmed (2007) discussions about the maintainability of operational issues of a waqf based MFI. The creator joins Islamic financial destinations and Islamic financial targets and promoters for Islamic money related area to incorporate social measurements in their tasks alongside business goals. This will be in type of financing the poor to build their riches and salary through different pertinent Islamic monetary contracts, for example, qardhasan, addressing fundamental needs and financing smaller scale business people. He likewise contends that Islamic money has been overwhelmed by Islamic banks that go to bigger firms simply like its ordinary partner.

In spite of thorough dialog on the waqf based microfinance, the creator has not built up a reasonable model that could be executed.

Fundamental to the test of engaging poverty is making riches through improvement of microenterprises (Obaidullah, 2008). Islamic way to deal with neediness lightening is more far reaching and more thorough than either moderate or maximalist approach. Despite the fact that the maximalists have endeavored to join non-money related parts of supporting the poor to exit from neediness however neglect to breeze through a moral trial of Shari'a consistence in business and budgetary exercises for the Muslims poor (Mohammed, 2010).

As respects to the possibility of the model in Bangladesh, the model will fit the objective network for the accompanying reasons. Initially, the abounding Muslims population in Bangladesh and being the most crowded Muslims nation in Asia and fourth biggest among OIC part nations is the main factor to understand the model's goals. This potential makes an open door for presenting and executing small scale venture that count with Muslim conviction framework. This potential could likewise put the nation as a desire for Islamic money related item in Bangladesh. Besides, rejection of significant number of individuals that require financing may almost certainly make open door for Islamic Micro-venture as an elective source that completely consent to confidence and culture of the Muslims. Thirdly, high protection from enthusiasm among the Muslims loyal would clear route to the enormous acknowledgment of Islamic smaller scale speculation display.

Research discoveries by Frishman (1986) on little scale ventures in different divisional cities (1973 and 1980) which is the most Muslims overwhelmed area in Bangladesh show high level of protection from enthusiasm among the private company business people. In this way the interest of Islamic microfinance is high likewise because of the disapprove of certain Muslims to customary microfinance in Bangladesh in security of their confidence. The significance of distributive equity can't be thought little of. Qur'an section 7 stanza 10 expressed completely the significance of equity and kindness in exchanges. Along these lines, the adherents are urged to grasp money related exercises that advance the team. This order can be seen in association that shares dangers and return, for example, Mudaraba, Musharaka and so forth. Not at all like obligation financing contracts, has association contract included both the responsibility of both lender and operator in the result conveyance along these lines improving proficiency and efficiency.

Essentially, the order in the Qur'an section 59 stanza 7 precludes riches focus among couple of individuals from the general public. The stanza elevates acquiescence to Allah in all issues 
including budgetary exchanges. The section exhibits that riches and assets at last has a place with Allah and human fills in as an overseer. The refrain braces that riches and assets must not be packed in few hands in this way; it must be flowed through organizations and other legal exchanges.

\subsection{Islamic Microfinance versus Islamic Micro-Investment Model}

Islamic Micro-Finance Model (IMFI) can be characterized as a business adventure in accordance with the Shari'ah prerequisite of money, expected to provide food for the financial needs of the poor in the general public. Islamic microfinance is essentially a microfinance that utilizes Islamic money related standards in giving budgetary administrations to poor people. It has been created because of the trepidation of certain Muslims in various nations and networks due the conviction that ordinary microfinance disregards Islamic standards of money. At the end of the day, Islamic microfinance is grown simply like the manner in which Islamic banking has created to conquer the hindrances innate in the customary microfinance. In this way it fills in as an option in contrast to the ordinary microfinance.

Notwithstanding, the act of Islamic microfinance again raises a caution on the bungle between the Islamic financial matters and account destinations with that of the establishments offering Islamic microfinance. In view of this foundation, the exploration wanted to build up a model that will guarantee business accomplishment with financial goals of the Muslims people group. The IMFI can be connected by any Islamic microfinance establishment that has the double goals of achieving gainfulness and advancing financial welfare of the general public. The Islamic money (for example the soul of the laws) is a moral rule to guarantee that a few or the majority of its assets for speculation are utilized to redistribute riches in the general public at beneficial dimension, for example, through microfinance (Farook, 2007). This can be accomplished by applying a plan that has the double goals of the individuals from the general public as expressed before. Likewise, the name of the model "Islamic Micro-Investment Model" gives diverse positive impressions and makes roads for applying the underestimated and under-connected Islamic budgetary contracts especially authentic association regardless of its potential advantages. Abdul Rahim (2010) for example, advocates that benefit and misfortune sharing plan can possibly lessen discriminatory dissemination of riches and salary just as guarantee ideal portion of assets contrasted with the premium based game plan.

The IMFI proposed will beat a portion of the real difficulties of Islamic Microfinance, for example, cost of capital, human asset need or more all destitution mitigation by focusing on various fragments of the general public. This can be accomplished by activating the inert assets explicitly waqf of various sorts including money waqf. Along these lines, the model could be depicted as what Haneef (2011) instituted as 'morally predominant' by fusing waqf in it since waqf is deliberate not normal for zakat which is compulsory. More or less, hypothetically, Islamic microfinance should fill a similar need with Islamic Micro-Investment Model while for all intents and purposes receiving IMFM gives more monetary and social advantage than the current ruled obligation and murabaha-driven in Islamic microfinance.

\section{METHODOLOGY OF THE STUDY}

Information from this examination is gathered through organized meeting from 7 respondents and was dissected specifically. Information investigation in subjective research is characterized as the procedure of methodically seeking and scoring the meeting transcripts, perceptions notes, or other non-printed materials that the specialist aggregates to build the comprehension 
of the marvel (Sekaran and Bougie, 2010). The way toward breaking down subjective information transcendently includes coding or sorting the information. Fundamentally, it includes comprehending tremendous measures of information by lessening the volume of basic data, allotting them into classes, trailed by recognizing critical examples, lastly drawing significance from information and along these lines constructing a sensible chain of proof (Sekaran and Bougie, 2010). As indicated by Miles and Huberman (1994) there are commonly three stages in subjective information investigation: information decrease, information show and the making inferences. Extraordinary information decrease, as indicated by Ueda \& Sakugawa (2009) was the strategy used to uncover the fundamental significance of the announcements. In the expressions of these creators "marvel implies member's singular "experience" and quintessence signifies "the member's certifiable signifying" of the experience."

Following the past analysts, this exploration tends to one focal research question. That is, what is the appropriateness and relevance of Islamic small scale scheme demonstrate? The inquiry is then separated into sub questions and the reactions created were considered as subjects of the examination discoveries as for every one of the inquiries. The exploration utilizes phenomenological technique for request to set up exhaustive comprehension of the phenomenon under request. The technique helped us to get general implications from explicit encounters of the talked with people (Moustakas, 1994). The respondents were made the inquiries on the topic and their individual reactions were coded and broke down all the while to create subjects and sub-topics significant to the issues raised. Accordingly, the examination discoveries were gotten from the announcements made by the specialists. The information utilized in this examination is essential information accumulated through overview. The exploration received semi-organized meeting. Topics rise up out of the exploration respondents met.

\subsubsection{Population and Sampling Techniques}

Seven specialists were met in the exploration between January, 2018-March 2019. These specialists involved three government authorities from Sharia Implementation, Zakat and Waqf and journey Boards separately. One master originates from Central Bank of Bangladesh (CBB) and the staying three were private advisor, academician and a fiqhscholar separately. All the met were recorded and translated for investigation. All things considered, every session kept going 20-25 minutes. The analyst utilizes purposive inspecting system to draw the respondents dependent on their skill and importance to the examination center. At first, some prior contacts were made to request for their eagerness to take an interest in the exploration. Upon their commendation, suitable time and setting were controlled by the interviewee and the specialist followed up for the meeting sessions.

\subsubsection{Study Area}

The investigation centers on different division in Bangladesh. The division is the second business Center and named 'Focal point of Commerce' in the nation. The division includes different ethnic gatherings that take part in various financial exercises in the division. In Bangladesh government characterizes these private companies into 16 specific markets seeking after various specializations of finance exercises, for example, carpentry, nourishment, essential goods, vegetables, and meat, handcrafts and machines markets. 


\section{RESULT AND DISCUSSIONS}

The consequence of the overview reveals some essential discoveries that achieve numerous other appropriate issues for hypothetical and commonsense thought. It additionally gives light on other vital issues to be tended to in future inquire about. In this area we talk about a portion of the discoveries dependent on subjects created. The principal topic that rises is Microfinance as an inventive instrument of battling destitution. Larger part of the respondent trusts that microfinance is required and is a correct mediation procedure for battling destitution. The reaction above and the neediness level demonstrated in statistic profile of the respondents portrays the requirement for Islamic small scale venture show mediation as a dependable creation procedure that is proposed dependent on the conviction and culture of the respondents. Additionally, the model's system is to fuse aptitudes of the poor that will be bridled and upheld suitably so as to lighten the threat of destitution. By and by, the span of supply neglects to equivalent with the interest, therefore this may have suggestion on the microfinance providers, for example, private, government and NGOs since right now the extent of microfinance request met is exceptionally low. As per Anyanwu (2004) it is below 1 percent of the all-out credit required in the economy.

In spite of the fact that the respondents have bolstered microfinance advancements, yet it appears there is a dread of disappointment because of past encounters of microfinance software engineers specifically and destitution annihilation procedures set out by the progressive political and military organizations previously.

The issue ascended by the respondent with respect to the disappointment especially government based microfinance incorporate botch, numbness of the general population and intrigue charge on advances. The Islamic small scale speculation demonstrate was created with remarkable element that makes it unmistakable from different past endeavors so that it attempts to limit enormously the weaknesses with such endeavors left upon.

The created model has obviously tended to the moral issue related with existing traditional microfinance which is the second topics produced. The moral issue is the thing that attempts IMFI not quite the same as different endeavors. The model has dealt with the conviction and culture of the general population which is a standout amongst the most antagonistic issues among the Muslim's people group. The consistency of the moral angle with conviction and culture impact the result of expectation which fills in as solid pointer for adequacy of the model among the network individuals. The consistence of the Islamic smaller scale venture show with Islamic money related standards has made it to separate itself with anything that includes premium, vulnerability, betting, theory and so forth. These denied components lock monetary assets from being profitably used. Then again, the model advances adventures, exchange and association, common collaboration and improvement of small scale undertakings. Azid, Asutay and Burki (2007) advocate that incorporating the moral cum financial measurements will improve the proficiency dimension of the economy and increment social welfare administrations. More or less, Islamic miniaturized scale speculation model will get acknowledgment in overwhelming Muslim people group as methods for battling neediness because of its consistence with Islamic monetary standards. The third subject is the pertinence of the essential Islamic budgetary contracts, for example, ijarah, Musharaka and mudaraba. The IMFI demonstrate was discovered amazing by the respondents as it fulfills the social conviction framework due its creation of these Islamic contracts. As indicated by the prominent view, the key Islamic monetary contracts, for example, Musharakah, Mudarabah, Ijarahetc are discovered relevant relying upon the division or gathering included. For example, in 
horticulture, the agreement could be called Muzara'a where the capital supplier and the rancher consent to share the returns dependent on pre-concurred proportion. Saad (2011) found that these Islamic monetary contracts are appropriate to fund diverse financial exercises in Malaysia. Despites this arrangement, a few examinations alert the utilization of a portion of these agreements in microfinance given its little nature of capital. Ahmed (2007) opined that agreements like murabaha and ijraha are increasingly suitable where data unbalanced exist. Ledgerwood (1999) advocates that stringent conditions in the microfinance are because of surreptitiously nature of the exertion of the operator, and these conditions could have been diminished or expelled on the off chance that it is turned out to be recognizable. For the specialists, one can contend for setting based and case by case uses of agreements. The fourth topic tends to the structure of the model. The structure of the model has fulfilled the specialists' perspectives. The model based the experience of the respondent considers methods for directing the assets fittingly. It is in accordance with that the model propose method of screening the in this way investigating the important potential and aptitudes of the customer before intercession is made. This evaluation comprises another vital stage which has not been caught in every single past exertion and it is gone for achieving harmoniousness between individual abilities and the business condition. Chapra (1992) keeps up there must be a separating component in the arrangement of Islamic financial matters and fund to supplement the market framework (Chapra, 2011). This ought to likewise be finished with alert to abstain from inferring out right customers. As indicated by Usmani (1999) Islamic money related foundations are business organizations as well as they are likewise compelled by a solemn obligation to advance the framework since they are based on a specific theory. In this manner applying organizations plan atleast on a particular premise before it advance and get out any type of untrustworthiness. As indicated by him, this will set points of reference in the market and prompt different IFIs to pursue the suit. The fifth topic that rises is manageability of microfinance by means of waqf. It is exceptionally evident that the wellspring of capital for whatever microfinance now and then introduces an issue in accomplishing goal of an activity. Islamic small scale assumption display has consolidated waqf to sponsor the microfinance especially in type of preparing.

IMFI will serve a counter activity to ordinary microfinance that considers the expense of capital independent of the wellsprings of assets whether from business money related foundations or from stores of the members; loan cost should at present be paid. As indicated by the training, poor are viewed as increasingly dangerous in light of the fact that they don't have credit record and the required security in the event of default, along these lines, their loan cost will in general be higher (Ledgerwood, 1999). The circumstance turns out to be progressively entangled when the regulatory expense are taken into contemplations. Presenting waqf in the Islamic miniaturized scale venture will decrease generously the expense of capital on the supply side and increment the human capital improvement through preparing on the interest side.

The 6th subject arrangements with prospects for development and IMFI display was created to convey prospects to the organizations of the smaller scale business visionaries as it contemplates the possibilities miniaturized scale business visionaries. The model burdens the abilities and possibilities regardless of sexual orientation. The model has more extensive degree that conveys along family, people and gathering. The more extensive degree coordinates other section of populace, for example, widows. Consequences of tests demonstrate that ladies are commonly great accomplices to the extent smaller scale financing is worried as there were observed to be dependable in the event of Zakat \& Hubsi house in Bangladesh. 
The seventh subjects manages stage through the model could be executed. With respect to the stage, disparate perspectives have been given. A portion of the respondents were of the view that Islamic Institutions/NGOs ought to be utilized, others bolster abandoning it open to any foundation willing and ready to work microfinance. In that manner, the effort of poor people could be improved by having numerous potential foundations willing and ready to execute it including government and private based microfinance establishments.

The stage of actualizing IMFI, despite the fact that is essential at the same time, the key angle is to give road where there will be full consistence of the model's arrangements. This finding is predictable with the proposals of the International Conference on Financing for Development (ICFD, 2002) which expressed that "improvement banks, business banks and other financial establishments whether freely or in participation, can be powerful instrument for encouraging access to back, including value financing, for such endeavors".

In the eighth subject the agreement that developed among the respondents is the mindfulness issue that may almost certainly fill in as one of the real difficulties that could confront the proposed model. It is found that few great activities and software engineers got set back because of lacking satisfaction among the general population. Truth be told, it is a typical a conviction that southern piece of Bangladesh will in general advantage more than the northern part the extent that activities are concerned, essentially because of the issue of mindfulness which has to do with formal instruction, preparing, illumination, open crusade and job of media. These media have been more promptly accessible in the south than its partner north. The errand of making the model progressively open ought to be a need amid usage so as to bring more recipients. Huge mindfulness crusade in spots of social occasions, for example, mosques, open talks, courses and workshop could be useful toward this path. The component of mindfulness will establish distinctive elements of the model, for example, financial points of interest, religious ramifications and advertising perspectives among others.

\section{CONCLUSION}

This examination venture perceives Islamic smaller scale money as a vital segment in poverty lightening methodologies. While ordinary microfinance items have been effective in Muslim greater part nations, these items don't satisfy the necessities of every Muslim customer. Consolidating the Islamic social guideline of thinking about the less lucky with microfinance's capacity to give money related access to the poor can possibly connect with millions additional individuals, a significant number of whom state they would favor Islamic substances over customary microfinance items. This exploration paper embraces a contextual analysis of Akhuwat, an Islamic microfinance association working in Bangladesh. Basic money related investigation of Akhuwat demonstrates that it is giving its administrations to all living below the poverty line including the "contemptible poor" and Interest free credits can be utilized as a useful asset against destitution. However Loan portfolio gorwth of Akhuwat decreases with the sharp decay of value development throughout the most recent 5 years that may represent some constraints on its financial steadiness in future. This test could be overwhelmed by coordinating Islamic microfinance with NGOs Zakah, Awqaf and with Takaful just as with expert preparing and very few organizations in Bangladesh to give Islamic microfinanicial administrations to the most unfortunate of the poor under one rooftop. It will inspire the expectation for everyday comforts of individuals and eventually contribute towards the financial advancement and improved success of the nation. 


\section{References}

Adewale, A. S., Platt, D. M., \& Spealman, R. D. (2006). Pharmacological stimulation of group ii metabotropic glutamate receptors reduces cocaine self-administration and cocaine-induced reinstatement of drug seeking in squirrel monkeys. Journal of Pharmacology and Experimental Therapeutics, 318(2), 922-931.

Ahmed, S., \& Reddy, L. A. (2007). Understanding the mental health needs of American Muslims: Recommendations and considerations for practice. Journal of Multicultural Counseling and development, 35(4), 207-218.

Beck, T., Demirguc-Kunt, A. S. L. I., Laeven, L., \& Levine, R. (2008). Finance, firm size, and growth. Journal of Money, Credit and Banking, 40(7), 1379-1405.

dan Kontemporari, P. I. (2018). ISLAMIC HOME FINANCING PRACTICES IN SELECTED OIC COUNTRIES: AN ASSESSMENT IN THE LIGHT OF MAQASID AL-SHARIAH. Jurnal Penyelidikan Islam dan Kontemporari, 1(1), 10-19.

Emran, M. S., Robano, V., \& Smith, S. C. (2014). Assessing the frontiers of ultrapoverty reduction: evidence from challenging the frontiers of poverty reduction/targeting the ultra-poor, an innovative program in Bangladesh. Economic Development and Cultural Change, 62(2), 339-380.

Farook, S. (2007). On corporate social responsibility of Islamic financial institutions.

Gow, I. D., Ormazabal, G., \& Taylor, D. J. (2010). Correcting for cross-sectional and time-series dependence in accounting research. The Accounting Review, 85(2), 483-512.

Haneef, M., Ahmad, I., Afaq, A., \& Rahman, A. (2011). The investigation of spherical effects on the photodetached electron spectra. Journal of Physics B: Atomic, Molecular and Optical Physics, 44(19), 195004.

Hess, J. R., Brohi, K., Dutton, R. P., Hauser, C. J., Holcomb, J. B., Kluger, Y., ... \& Hoyt, D. B. (2008). The coagulopathy of trauma: a review of mechanisms. Journal of Trauma and Acute Care Surgery, 65(4), 748-754.

Hess, J. R., Brohi, K., Dutton, R. P., Hauser, C. J., Holcomb, J. B., Kluger, Y., ... \& Hoyt, D. B. (2008). The coagulopathy of trauma: a review of mechanisms. Journal of Trauma and Acute Care Surgery, 65(4), 748-754.

Karnani, A. (2007). The mirage of marketing to the bottom of the pyramid: How the private sector can help alleviate poverty. California management review, 49(4), 90-111.

Karnani, A. (2007). The mirage of marketing to the bottom of the pyramid: How the private sector can help alleviate poverty. California management review, 49(4), 90-111.

Kono, H., \& Takahashi, K. (2010). Microfinance revolution: Its effects, innovations, and challenges. The Developing Economies, 48(1), 15-73.

Mendola, M. (2007). Agricultural technology adoption and poverty reduction: A propensity-score matching analysis for rural Bangladesh. Food policy, 32(3), 372-393.

Miles, M. B., Huberman, A. M., Huberman, M. A., \& Huberman, M. (1994). Qualitative data analysis: An expanded sourcebook. sage.

Mohammed, S., Ferzandi, L., \& Hamilton, K. (2010). Metaphor no more: A 15-year review of the team mental model construct. Journal of management, 36(4), 876-910.

Moustakas, C. (1994). Phenomenological research methods. Sage.

Obaidullah, M. (2008). of the Book: Introduction to Islamic Microfinance.

Obaidullah, M. (2008). of the Book: Introduction to Islamic Microfinance.

Rahim, N. A., \& Selvaraj, J. (2010). Multistring five-level inverter with novel PWM control scheme for PV application. IEEE transactions on industrial electronics, 57(6), 2111-2123.

Razak, D. A., \& Tazwar, F. (2018). Islamic Home Financing Practices In Selected Oic Countries: An Assessment In The Light Of Maqasid Al-Shariah. Journal of Islamic Management Studies, 1(2), 1-11.

Sekaran, U. Bougie (2010). Research methods for business: A skill building approach.

Sekaran, U., \& Bougie, R. (2010). Theoretical framework in theoretical framework and hypothesis development. Research methods for business: A skill building approach, 80 .

Shetty, R. P., Endy, D., \& Knight, T. F. (2008). Engineering BioBrick vectors from BioBrick parts. Journal of biological engineering, 2(1), 5 .

Sieving, P. A., Frishman, L. J., \& Steinberg, R. H. (1986). Scotopic threshold response of proximal retina in cat. Journal of Neurophysiology, 56(4), 1049-1061.

Sieving, P. A., Frishman, L. J., \& Steinberg, R. H. (1986). Scotopic threshold response of proximal retina in cat. Journal of Neurophysiology, 56(4), 1049-1061.

Yunus, M. B. (1983). Fibromyalgia syndrome: a need for uniform classification. The Journal of rheumatology, 10(6), 841.

Zhou, B. B. S., Zhang, H., Damelin, M., Geles, K. G., Grindley, J. C., \& Dirks, P. B. (2009). Tumour-initiating cells: challenges and opportunities for anticancer drug discovery. Nature reviews Drug discovery, 8(10), 806. 